\section{I $\mathbf{B}$ Anstitute of \\ YK Business Administration \\ तर Karachi \\ Leadership and Ideas for Tomorrow}

Article 1

Volume 10 Issue 1 January - June 2015

$1-1-2015$

\title{
Front Matter of Volume 10 Number 1
}

Tufail A. Qureshi

Institute of Business Administration Karachi, Pakistan

Follow this and additional works at: https://ir.iba.edu.pk/businessreview

Part of the Business Commons

(c) (i)

This work is licensed under a Creative Commons Attribution 4.0 International License.

\section{Recommended Citation}

Qureshi, T. A. (2015). Front Matter of Volume 10 Number 1. Business Review, 10(1), 1-4. Retrieved from https://doi.org/10.54784/1990-6587.1309

This article is brought to you by iRepository for open access under the Creative Commons Attribution 4.0 License and is available at https://ir.iba.edu.pk/businessreview/vol10/iss1/1. For more information, please contact irepository@iba.edu.pk. 
Volume 10 Number 1 January - June 2015

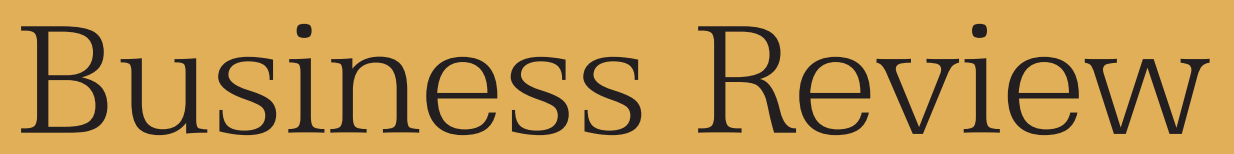

Leadership and Ideas for Tomorrow

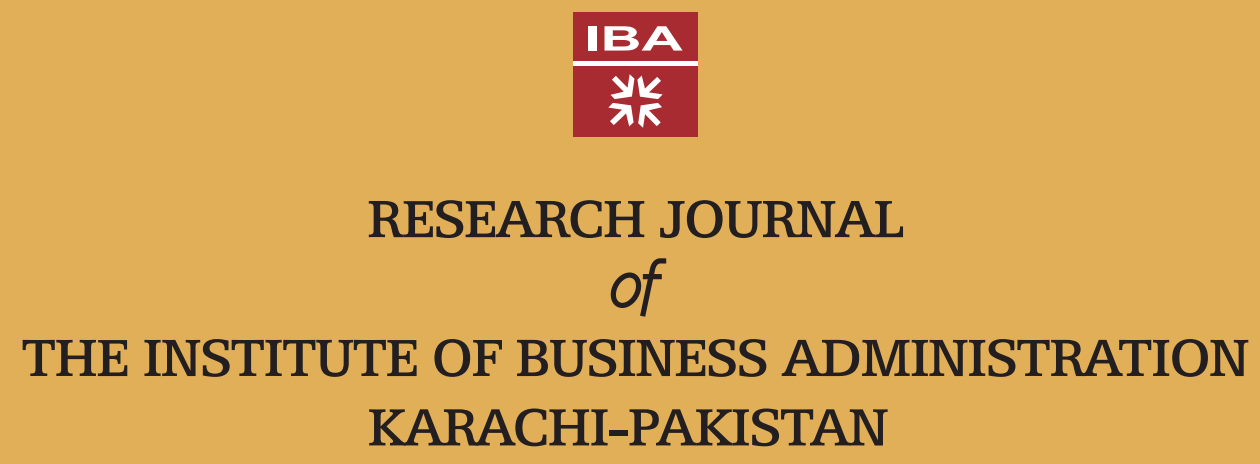


https://ir.iba.edu.pk/businessreview/vol10/iss1/1

DOI: https://doi.org/10.54784/1990-6587.1309

\title{
IBA \\ 药 \\ तर
}

\section{BUSINESS REVIEW}

\author{
Volume 10 Number 1
}

January - June 2015

\section{INTERNATIONAL EDITORIAL BOARD}

Ishrat HUSAIN

Chairman Board of Editors
Tufail A. QURESHI

Editor
Deepak KAPUR

Institute of Management Technology Ghaziabad, UP, India

Khurshid M. KIANI

Bang College of Business, Almaty Republic of Kazakhstan

S.W.S.B. DASANAYAKA

University of Moratuwa, Sri Lanka

Menno ADEN

Technische University, Dortmund Germany

Liu Jun YING

Jinanjin University, Jian Jin, China

Naved AHMED

Institute of Business Administration, Karachi, Pakistan

M. Aminul ISLAM

University Sain, Malaysia

Bettina ROBOTKA

Humbolt University, Berlin Germany

Akif HASSAN

Iqra University, Karachi-Pakistan

Khursheed OMER

University of Houston, Downtown Texas USA

Zeenat ISMAIL

Institute of Business Administration, Karachi-Pakistan

Huma BAQAI

Institute of Business Administration, Karachi, Pakistan
Arun Diwaker Nath BAJPAI

Rani Durgavati University, Jabalpur, (MP) India

Talat A. WAZARAT

Institute of Business Administration Karachi-Pakistan

Shamas-ur-Rehman TOOR

University of New South Wales, Australia

Khadija Malik BARI

Institute of Business Administration Karachi-Pakistan

Ahmed Audu MAIYAKI

Bayero University, Kano Nigeria Agung NUGROHO

Atma Jaya Cotholic University, Jakarta, Indonesia

Faisal Manzoor ARAIN

Southern Alberta Institute of Technology Canada

Low Sui PHENG

National University of Singapore

Badar Alam IQBAL

Aligarh Muslim University Aligarh,(UP) India Abdul RASHID

Intrnational Islamic University, Islamabad-Pakistan

Mirza Sardar HUSSAIN

Institute of Business Administration, Karachi-Pakistan Nadir Ali KOLACHI

Sky Line University, U.A.E

Dan QU

Hunan University, China

Business Review is a peer reviewed bi-annual research journal of the Institute of Business Administration (IBA) Karachi. It is recognized by the

Higher Education Commission (HEC) of Pakistan and is internationally abstracted/ indexed in the Journal of Economic Literature (JEL) and EBSCO database.

Business Review is a non profit Organization 
https://ir.iba.edu.pk/businessreview/vol10/iss1/1

DOI: https://doi.org/10.54784/1990-6587.1309

\title{
BUSINESS REVIEW
}

\author{
IBA \\ 泉
}

RESEARCH JOURNAL

of

THE INSTITUTE OF BUSINESS ADMINISTRATION

KARACHI - PAKISTAN 


\section{CONTENTS}

Editorial Perspective

\section{ARTICLES}

Revisiting compensating wage differentials: the evidence from employer-provided health insurance

\section{Dan Qu}

The ex-dividend day stock price behavior: evidence from pakistan

Profiling organizational culture of different

Zaki Rashidi, Nadeem A Syed, Sajida Zaki

What lies at the core of core inflation? An empirical analysisto identify the

Mehwish Ghulam Ali, Muhammad Ather Elahi, Qazi Masood Ahmed

Asset price bubbles with specific focus On stock prices in pakistan

Nawaz Ahmad, Rizwan Raheem Ahmed, Yaseen Ahmed Meenai

Determinants of capital structure of service and manufacturing sectors of pakistani companies listed in karachi stock exchange

Zahid Ali Channar, Manisha Bai Maheshwari, Piribhat Abbasi

AMO framework and psychological empowerment: conceptual model decoding the black box between hrm and innovative work behavior Wali Ur Rehman, Mansoor Ahmad

Impact of board characteristics and audit committee on financial performance: a study of manufacturing sector of pakistan

Arfan Ali, Saad Bin Nasir

But math is my subject' - a study of motivational beliefs and selfregulated learning as a predictor of goal orientation in secondary school students

Shamila Nabi Khan, Maria Khan

Evaluation method, task outcomes and group structure as counteracting strategies of social loafing in manufacturing industries of pakistan Khurshid Alam, Arshad Ali, Fazli Subhan

\section{CASE STUDY}

Easypaisa: seizing the white space and business Model innovation

Global alliance approach for effectiveness of

Higher education in business studies - a case approach

Arup Barman,

\section{COMMENTARY}

Measuring work stress of marketing professionals

Nauman Abdullah, Shaukat Ali Raza, Mahr Mohammad, Saeed Akhtar

\section{BOOK REVIEW}

Why nations fail: a review article

Ashutosh Mani Dixit 
Editorial Perspective

\title{
TWO NARRATIVES and A DISCOURSE
}

\author{
"Remaking the world is an insignificant task." \\ "It is not the world that must be remade, but man." \\ Albert Camus, Notebooks 1942-1951, p.115
}

To rebuild the corporate world, we must strive to shift our paradigm, striving for an evaluative position in all the judgments we make, shifting our creative and co-creative emphasis away from the vaguely and partially defined position regarding the acceptance of thus it is and the taken for granted attitude to a radically examined position predicated on a creative and constitutive inter-subjective position based on the vision of clear and distinct perception of "thus it ought to be."

Although it is a single activity but the meaning is twofold. Firstly, it demands that we integrate into the corporate world-view the principle of movement which lends it the dynamic and transcendent possibility unfolding new, fresh and culturally oriented ways of being in the world. After all, why should the corporate world remain stigmatized by morbid ideas, petrifying beliefs and culturally retrograde attitudes and insipid lifestyle. It is needed to rethink the corporate world and to redefine its worldliness from a new perspective with a renewed sense of creative will, to rejuvenate new ways of making it a lived-world and a world we may call our world: the world which belongs to us and to which we belong.

Secondly, under the force of circumstance, it is imperative to revamp the conceptual structures and, more importantly, the idealizations of the corporate world to reflect the altered mood and temper of the man who feels that the shadows of the events that take place in the corporate world shall color his dreams and light the dawn of his hopes for tomorrow, and or a long time to come, if tomorrow comes.

To reach the desired goal, by moving in the right direction, it is indeed necessary to be on the right path and to move slowly and with measured steps, with the awareness that our supercilious attitude and a pious façade, will make us sink deeper into denial and bad faith. The corporate man is the measure of the genius of both the good and the evil of his heart and mind. And the measure of his sincerity lies in his honest-to-goodness realization that fatal flaws exist in the corporate system and need to be addressed before he is rendered transparent in our eyes and convicted in his mind. He needs to put his unexamined beliefs and ideas in parenthesis to contest the allegations that;

1. The corporate world is facing grave moral crisis generated by its own inherent fatal flaws.

2. The 'corporate system' is threatened by the lack of knowledge about the nature of man and what light does this knowledge shed on the place of Value in the corporate culture and or Decision making in the corporate management.

3. Human nature and decision making are closely allied to the value judgment and attitude formation. Crisis, typically characteristic of the corporate world, confronts our business leadership with serious challenges, laden with moral consequences. 
4. Remembering that the dubious ethical and moral practices and aberrations are not a monopoly of any system, how strong and convincing is the evidence that the corporate man does not suffer from grievous flaws of ethical conduct and moral behavior and that his character is above all reproach and denunciation?

5. Remembering also that the corporate functionary is not alone to suffer from moral lapses and that his ethical lassitude is human, all too human, and therefore not unjustly blame worthy in the context of human condition characterizing human situation.

6. In philosophy and in ethics, in life and in business, perennial questions of human relevance cannot be asked meaningfully outside the context of human situation.

Therefore, both from the negative and affirmative standpoints the persisting areas of controversy remain and the debate lingers on; E.g.:

a. How natural is human nature and,

b. In the domain of human nature, what is the place of moral commitment and obligation? In the realm of value, is a free man by nature free to "enjoin the good and forbid the wrong?"

c. Is he obliged to obey unjust corporate system incapable of rising above himself? He needs to remember that "unless above himself he can raise himself, what a poor thing is man!"

d. Is human nature immutable? Is, by nature, a criminal condemned to remain a criminal and a poor man poor? Jean Paul Sartre, an existentialist philosopher, believes that 'man is condemned to be free', free to make and re-make himself, free to determine his destiny and his fate?, to give himself a nature and a character by his actions, decisions, evaluations and choices; by the way he exercises the freedom and his will to power.

e. A free man is a 'particular universal'. He follows the Kantian categorical imperative 'to act in such a way that by his will his action becomes a law universal'.

f. To be free, the corporate man needs to have ethical insight to know the truth and moral courage to will the truth. Above all, he must have the fortitude to do what is right.

g. If he loves truth more than the thing he loves, does he uphold truth over and above his loyalty to whatever goes without saying and is taken for granted?

h. Does he follow and must he abide by the law he is convinced is morally wrong and is not predicated on truth?

i. As a lover of truth, is he willing to seek the truth everywhere or nowhere, at all?

j. Straying from truth for so long, does he have the courage and character to outgrow his vehement insistence on thus it is and it cannot be otherwise? Consider then the narratives and the discourse, rational and human, constructed with so much understanding by
a. Socrates in Apology
b. Sophocles in Antigone
c. Thomas Hobbes in Leviathan
d. David Hume in A Treatise of Human Nature
e. Immanuel Kant in his Critique of Practical Reason

The desire to reconcile the antithetical and antagonistic notions regarding "to be or not to be", 'thus it is' and 'thus it ought to be' has dominated human mind and soul ever since the advent 
of his reflective consciousness, and the problem of freedom has agonized him like a thorn in his heart.

Freedom, like character, is the most precious possession of man. In nothing else is he rich, in nothing else is he poor. Nothing in man's life is more vital and glorious than the character of a free man. But once it is dead, it is dustily dead and lost forever.

"I think we have freedom of will and that it comes out of our uniqueness as individuals, perhaps wholly determined, yet to some degree unpredictable, it is one of our most precious possessions. As such, we should seek to enlarge it; yet that is not the direction in which we are going. On the contrary, many aspects of modern life threaten to erode it; and much that we are offered in the guise of future progress would tend to do the same,"

John R. Platt, New Views of the Nature of Man, p.46

No strategy can be effective and relevant to rebuilding the corporate worldview without an ethical perspective. In the corporate world today, more than ever before, there exist growing need to place our unexamined beliefs and assumptions, in parenthesis for radical examination not only because they have not been questioned and radically examined before but more so because they have become sacrosanct. We must not transgress our fidelity to truth expediency and personality above character.

Our focus must now shift from knowing to being and in the ontogenetic realm of thinking we must develop fresh phenomenological attitude enshrined in its creative and dynamic spirit that will unfold the principle of transcendental movement. Our success in this regard will reflect dynamic spirit of the creative enthusiasm, methodological interpretation and the dynamic and transcendental spirit of our corporate worldview. It will radically deepen our understanding of man's-being-in-the-world, converging upon "to be or not to be" what we know and understand. This is a step closer to rebuilding the Corporate World by assiduously reconstructing the Corporate Man. Sadly, however, and it is writ large all over Corporate Pakistan, our dismal success in this respect betrays our huge failure as a man.

To achieve this goal we need to develop new analogies and new metaphors, new ways of seeing the world and new ways of being in it; above all being what we know and understand and are capable of becoming. All these possibilities are embedded in man's beingin-the-world, waiting to be translated into defining features of world to be, via man's courage to be and the efficacy of his creative imagination and the will to truth.

This is the most perilous part of the undertaking; to search and then to destroy the hidden persuaders, working anonymously and subliminally, they take ownership of our thoughts, emotions and the power to decide and choose to determine our value-judgments and attitudes. It is as if they know our heart and soul and mind. The corporate functionary has to rise above the stigmatizing and petrifying status quo, transcending his parochial inclinations to test the strength of purpose and the total integrity of his character, demonstrated in his conduct and behavior as a sine qua non and quintessential of his business organization's reputation and positive perception. The moral proclivity, phenomenological assumptions and presuppositions have built-in answers which must not be allowed to remain obscure to the creative imagination and the will to truth of the corporate man. Such proclivity and stinted bias have a decisive impact upon the profit orientation and financial bottom line of corporate business. They constitute the defining features of its identification and raison d'etre. 
pIn this context, we need to examine

i. The nature of Acquisitive Ideal and Profit Motive (Peter Drucker)

ii. $\quad$ A New Code of Business Ethics (B. Randall)

iii. Business Morality; Some Unanswered (and perhaps unanswerable) Questions (A.S. Aitler)

iv. Thinking through Corporate Social Responsibility. Arguments for and Against (Richard Eells and Theodore Levitt)

v. Responsible Advertising, The Truth or the Product? (Games Webb Young)

vi. The Hidden Persuaders (Vance Packard) 'and Idols of Mind (Bacon)

vii. The Ethics of Persuasion and The Art of Selling (Aldous Huxley)

... to be continued

Tufail A Qureshi

Beneath every serious dispute in the world of scholarship lies a judgment of value; and when that point is reached, science and scholarship must bow their heads in silence. Only one voice may still be heard; the voice of philosophy. There speaks reason. All else is only cries of emotion. Emotion is individual; transient. Reason is permanent.

Gilber Highet, Man's Unconquerable Mind, pp 96 